\title{
Cellular Calcium Distribution Modulates the Growth of Callus and Protoplasts of Halophyte Mangrove Plant, Avicennia Alba - an X-ray Microanalysis
}

\author{
Manabu Hayatsu ${ }^{1,2,3}$, Suechika Suzuki ${ }^{1,2}$, Shinpei Tsuchiya ${ }^{4} \&$ Hamako Sasamoto ${ }^{2,5}$ \\ ${ }^{1}$ Department of Biological Sciences, Faculty of Science, Kanagawa University, Hiratsuka, Kanagawa 259-1293, \\ Japan \\ ${ }^{2}$ Research Institute for Integrated Science, Kanagawa University, Hiratsuka, Kanagawa 259-1293, Japan \\ ${ }^{3}$ Division of Microscopic Anatomy, Graduate School of Medical and Dental Sciences, Niigata University, \\ Niigata, 951-8510, Japan (present address) \\ ${ }^{4}$ Graduate School of Environment and Information Sciences, Yokohama National University, Yokohama \\ 240-8501, Japan \\ ${ }^{5}$ Faculty of Environment and Information Sciences, Yokohama National University, Yokohama 240-8501, Japan \\ Correspondence: Hamako Sasamoto, Research Institute for Integrated Science, Kanagawa University, Hiratsuka, \\ Kanagawa 259-1293, Japan. Tel: 81-463-59-4111. E-mail: sasamoto@ynu.ac.jp
}

Received: February 13, 2017

Accepted: March 11, 2017 Online Published: March 28, 2017

doi:10.5539/jps.v6n2p18

URL: https://doi.org/10.5539/jps.v6n2p18

\begin{abstract}
Two cultured cell lines were developed from cotyledons of a halophyte mangrove, Avicennia alba. In the high-Ca callus line, which was sub-cultured in a modified amino acid medium containing $3 \mathrm{mM} \mathrm{CaCl}_{2}$, growth of calluses and their protoplasts were both inhibited by low concentrations of $\mathrm{CaCl}_{2}$ in the culture medium. Removal of $\mathrm{Ca}^{2+}$ from the culture medium stimulated callus growth and the calluses could be sub-cultured without $\mathrm{CaCl}_{2}$ (low-Ca callus line). The intra- (cytoplasmic matrix and vacuole) and extra- (cell wall) cellular concentrations of elements, i.e., $[\mathrm{Ca}],[\mathrm{K}],[\mathrm{Cl}],[\mathrm{Na}],[\mathrm{Mg}],[\mathrm{P}]$ and $[\mathrm{S}]$ were investigated using quantitative $\mathrm{X}$-ray microanalysis of cryosections of calluses from both cell lines. [Ca] was high in the cytoplasmic matrix and cell wall of the high-Ca line. [Ca] was lowered in the low-Ca line in all cell compartments, though still detected. Ca-containing electron-dense precipitates were accumulated in the middle lamella of cell walls in resin-embedded sections of the high-Ca line. $\mathrm{CaCl}_{2}$ in the medium stimulated protoplast growth only in the low-Ca line. These results suggested that a low cellular $[\mathrm{Ca}]$ is needed for protoplasts growth of A. alba. The importance of cellular [Ca] for the growth of halophilic mangrove plant cells was discussed.
\end{abstract}

Keywords: $\mathrm{Ca}^{2+}$ ions, halophilism, mangrove plant cells, salts tolerance, $\mathrm{x}$-ray microanalysis

\section{Introduction}

Mangrove plants grow in brackish waters in tropical and subtropical areas. More than 100 species of different families of trees and woody plants and ferns are included in mangrove plants (Tomlinson, 1986; Spalding, Kainuma, \& Collins, 2010). Degree of salt tolerance differs considerably between species grown on the seaward side and those grown upstream. Avicennia alba and Sonneratia alba are halophyte mangrove species that can grow on the most seaward side of a mangrove forest. As it is difficult to grow young seedlings of mangrove species year round, cell cultures are excellent experimental systems to study the specific cellular mechanisms underlying the halophilism of mangrove plants (Kawana et al., 2007; Kawana, Sasamoto, \& Ashihara, 2008). Callus cultures of mangrove species were first produced using the pistil of $S$. alba (Akatsu, Hosoi, Sasamoto, \& Ashihara, 1996). Then suspension cultures were established using cotyledons of three Sonneratia mangroves species, S. alba, S. caseolaris and S. ovata, (Kawana et al., 2007; Yamamoto, Kawana, Minagawa, \& Sasamoto, 2011; Hasegawa, Oyanagi, Minagawa, Fujii, \& Sasamoto, 2014). Murashige and Skoog (MS) (Murashige \& Skoog, 1962) basal medium, which is commonly used in cultures of plant tissues, was used in these studies. The latter two Sonneratia species are less tolerant to $\mathrm{Na}^{+}$salt (Hasegawa et al., 2014). By contrast, in Avicennia mangrove species, only A. alba could be sub-cultured as a suspension culture in the modified amino acid (mAA) 
basal medium (Hayashi et al., 2009), in which the concentration of $\mathrm{CaCl}_{2}(3 \mathrm{mM})$ is the same as the MS basal medium. Though the halophilic nature to $\mathrm{Na}^{+}$and $\mathrm{Mg}^{2+}$ was shown in leaf culture of another seaward side grown mangrove species, A. marina (Hayashi et al., 2009), callus growth in sub-culture has not been established in Avicennia species other than A. alba.

We investigated the halophilic and salts-tolerant nature using cotyledon-derived suspension cultures of $S$. alba (Kawana \& Sasamoto, 2008) and A. alba (Hayashi et al., 2009) and their protoplast cultures (Hasegawa, Kurita, Hayashi, Fukumoto, \& Sasamoto, 2013). The effects of adding high concentrations (10-200 mM) of $\mathrm{Na}^{+}, \mathrm{K}^{+}$, $\mathrm{Mg}^{2+}, \mathrm{Ca}^{2+}, \mathrm{Cl}^{-}$, and $\mathrm{SO}_{4}{ }^{2-}$ ions in the medium, on the growth of suspension cells and protoplasts were investigated. These ions are constituent ions in seawater and soil and the habitat of mangrove plants contain various amounts of each ion (Dagar, Singh, \& Mongia, 1993). A. alba suspension cells showed tolerance or halophilism to $\mathrm{Na}^{+}, \mathrm{K}^{+}, \mathrm{Mg}^{2+}, \mathrm{Cl}^{-}$, and $\mathrm{SO}_{4}{ }^{2-}$ ions; however, further addition of $10 \mathrm{mM}$ of $\mathrm{CaCl}_{2}$, was inhibitory to growth (Hayashi et al., 2009), while $S$. alba suspension cells showed halophilic nature to all of the salts investigated including $\mathrm{Ca}^{2+}$ (Kawana \& Sasamoto, 2008). The protoplast cultures showed similar differences in $\mathrm{Ca}^{2+}$ effect between S. alba and A. alba (Hasegawa et al., 2013).

Previously, distribution of cellular elements, in cryosections of $S$. alba suspension cells was compared with that of glycophyte rice suspension cells (Hayatsu, Suzuki, Hasegawa, Tsuchiya, \& Sasamoto, 2014). We found that decrease of cellular $\mathrm{Ca}$ concentration ([Ca]) in the cytoplasmic matrix and vacuole was related to the halophilic nature of $S$. alba to $\mathrm{Na}^{+}$. This is likely through an increase of possible transport activities of $\mathrm{Na}^{+}$from cytoplasmic matrix into the vacuoles under the stress of additional $50 \mathrm{mM} \mathrm{NaCl}$ in the medium. This line of $S$. alba suspension culture was successfully sub-cultured in medium containing $50 \mathrm{mM} \mathrm{NaCl}$.

Here, we investigated the inhibitory effects of lower concentrations of $\mathrm{CaCl}_{2}$ on the growth of cotyledon-derived callus culture of $A$. alba which was newly induced in a mAA medium (Tsuchiya et al., 2013). Furthermore, a 'low-Ca callus line' was established by sub-culturing in the medium without $\mathrm{Ca}^{2+}$. To determine the cellular mechanisms underlying $\mathrm{Ca}^{2+}$ inhibition in callus culture of $\mathrm{A}$. alba, we studied the ultrastructural features of cells, and intra- (cytoplasmic matrix and vacuole) and extracellular (cell wall) $[\mathrm{Ca}]$ and concentrations of various elements, using electron probe X-ray microanalysis and compared the results with those of $S$. alba (Hayatsu, Ono, Hamamoto, \& Suzuki, 2012; Hayatsu et al., 2014). Effects of deletion of $\mathrm{CaCl}_{2}$ in the medium were also investigated on growth for their protoplast cultures. The mechanisms underlying the tolerance to salts and halophilic nature of mangrove cells were discussed.

\section{Method}

\subsection{Callus Culture of Avicennia alba}

Callus culture of A. alba was developed from cotyledons of crypto-viviparous seeds, collected in Thailand and stored in tap water as described previously (Tsuchiya et al., 2013). The calluses were sub-cultured at 4- to 8 -week intervals in 6-9 $\mathrm{cm}$ petri dishes. The culture medium was the modified amino acid (mAA) basal medium, containing various elements as the major salt components $(26 \mathrm{mM} \mathrm{Cl}, 21.25 \mathrm{mM} \mathrm{K}, 0.2 \mathrm{mM} \mathrm{Na}, 1.5 \mathrm{mM} \mathrm{Mg}$, $1.25 \mathrm{mM} \mathrm{P}$, and $1.73 \mathrm{mM} \mathrm{S}, 3 \mathrm{mM} \mathrm{Ca}), 1 \mu \mathrm{M}$ 2,4-dichlorophenoxyacetic acid (2,4-D), $1 \mu \mathrm{M}$ thidiazuron and $3 \%$ sucrose solidified with $0.8 \%$ agar. Sub-culture was performed in the medium with $3 \mathrm{mM} \mathrm{CaCl}$ (high-Ca line). About one year after induction of a high-Ca line, a low-Ca line was developed by sub-culture in the medium without $\mathrm{CaCl}_{2}$ after checking the growth in 0-6 $\mathrm{mM} \mathrm{CaCl}_{2}$ containing media (see Figure 2 in setion 3.1). Pure water (Milipore Elix or Direct Q UV, 18.2 M $\Omega$ ) was used for all culture media preparation. The pH was adjusted to 6.2 with $\mathrm{NaOH}$ and then autoclaved at $120^{\circ} \mathrm{C}, 20 \mathrm{~min}$. The petri dishes were kept at $30^{\circ} \mathrm{C}$ in the dark

\subsection{Effect of $\mathrm{CaCl}_{2}$ on Growth of High-Ca Callus Line of A. alba}

Effects of $\mathrm{CaCl}_{2}$ concentrations on growth of $A$. alba calluses were measured by using a 24-well culture plate containing $0.8 \mathrm{~mL}$ medium solidified with agarose (0.8\%, Type VII, Sigma A-4018) in a well. Cultures were incubated at $30^{\circ} \mathrm{C}$ in a humid incubator $\left(\mathrm{CO}_{2}\right.$-incubator without the supply of $\mathrm{CO}_{2}$ gas, APC-30DR, ASTEC Co. Ltd.). Photographs of callus in each well were taken with digital camera after 0 and $31 \mathrm{~d}$ of culture. By Image $\mathbf{J}$ (Rasband, 1997-2016) analysis (see Appendix), pixel area of callus was calculated as \% of the initial area. Data were averaged from two wells with standard deviation. Fresh and dry weights were measured after three months of culture.

\subsection{Protoplast Isolation and Culture of A. alba Callus}

Protoplasts were isolated from the A. alba calluses in axenic condition as described previously, with $1 \%$ each of Cellulase RS and Driselase 20 in 0.6 M mannitol solution (Tsuchiya et al., 2013). Protoplasts were washed with mannitol solution by centrifugation at $1300 \mathrm{rpm}$ for $5 \mathrm{~min}$ after purification on the density gradient on $0.6 \mathrm{M}$ 
sucrose. Protoplast culture was performed in each $50 \mu \mathrm{L}$ liquid medium using a 96-well culture plate as described previously for suspension protoplasts of A. alba (Hasegawa et al., 2013), except for osmotic condition. Basal medium was mAA containing $3 \%$ sucrose, $0.1 \mu \mathrm{M}$ or $1 \mu \mathrm{M}$ each of 2,4-D and thidiazuron and $0.6 \mathrm{M}$ mannitol with and without $3 \mathrm{mM}$ of $\mathrm{CaCl}_{2}$. Initial protoplast densities were $10^{4} / \mathrm{mL}$ or $5 \times 10^{4} / \mathrm{mL}$. Numbers of enlarged (more than $50 \mu \mathrm{m}$ diameter) protoplasts were counted in a well after 6 days of culture under an inverted microscope.

\subsection{Conventional Transmission Electron Microscopy and X-ray Microanalysis}

Two-week-old calluses of A. alba were mixed with agarose (Type VII, Sigma A-4018), which was dissolved (2\%) with liquid medium at $60^{\circ} \mathrm{C}$ for $20 \mathrm{~min}$, and solidified at room temperature. Calluses in agarose block were fixed with a $6 \%$ glutaraldehyde solution $(0.1 \mathrm{M}$ phosphate buffer, $\mathrm{pH} 7.2)$ for $12 \mathrm{~h}$ and post-fixed with a $2 \%$ osmium tetroxide solution overnight at $4{ }^{\circ} \mathrm{C}$. The fixed specimens were dehydrated with a graded acetone series and embedded in Quetol 812 epoxy resin (Nisshin EM Co. Ltd., Tokyo, Japan). The preparation of ultrathin sections, electron staining with uranyl acetate and lead citrate, and microscope observation were carried out as described previously (Hayatsu et al., 2012, 2014). X-ray microanalysis was performed as detailed in section 2.6 on the electron-dense precipitates at the middle lamella of cell wall in the resin-embedded sections without electron staining as described previously (Inoue et al., 2013).

\subsection{Preparation of Cryosections}

Calluses of A. alba were embedded in agarose as described in section 2.4. The method used for the cryosection preparation, freeze-drying, and the quantitative X-ray microanalysis was essentially the same as in our earlier studies (Hayatsu et al., 2012, 2014). Briefly, samples in agarose blocks were high-pressure frozen (EM-PACT, Leica, Austria) and stored in liquid $\mathrm{N}_{2}$. Cryosections prepared with cryoultramicrotome (Ultracut UCT/EM FCS, Leica, Austria) were freeze-dried (VDF300S, Vacuum Device, Inc., Mito, Japan) at $1.3 \times 10^{-4} \mathrm{~Pa}$ and $-80^{\circ} \mathrm{C}$ for 6 $\mathrm{h}$, and were lightly evaporated in vacuo with carbon. X-ray microanalysis was performed as detailed in section 2.6.

\subsection{X-ray Microanalysis}

Quantitative X-ray microanalysis of cryosections was performed as described previously (Hayatsu et al., 2012, 2014) using an analytical electron microscope (JEM 1230/MiniCup/EX-14033JTP: JEOL, Akishima, Tokyo, Japan) with a Be-stage holder or a cryotransfer holder (G626DH: Gatan, Tokyo, Japan), respectively. Elemental concentrations were calculated on the basis of the Peak/Background intensity ratio $(P / B$ ratio) using the software NORAN System SIX (Thermo Electron Co., Middleton, WI, USA) and the concentrations were indicated in $\mathrm{mmol} / \mathrm{kg}$ dry weight (DW). The experiments were repeated with independently prepared samples. Concentrations of each element from cryosections were averaged from ten values for each element, and the standard error was calculated from these values, respectively. The Student's $t$ distribution was used to determine the significances of difference between the elemental concentrations of calluses that were cultured with and without $3 \mathrm{mM} \mathrm{CaCl}_{2}$.

\section{Results and Discussion}

\section{1 $\mathrm{CaCl}_{2}$ Inhibition on the Growth of High-Ca Callus Line and the Development of Low-Ca Callus Line of A. alba}

Figure 1 shows the effects of $\mathrm{CaCl}_{2}$ on the growth of a callus of a high-Ca line sub-cultured on the mAA basal medium containing $3 \mathrm{mM} \mathrm{CaCl}_{2}$ for about two years after induction, quantitated by using a 24-well culture plate. Callus grew in medium containing $\mathrm{CaCl}_{2}$ at concentrations less than $1 / 10$ of that in the sub-culture medium, but growth was inhibited at higher concentrations of $\mathrm{CaCl}_{2}$. 


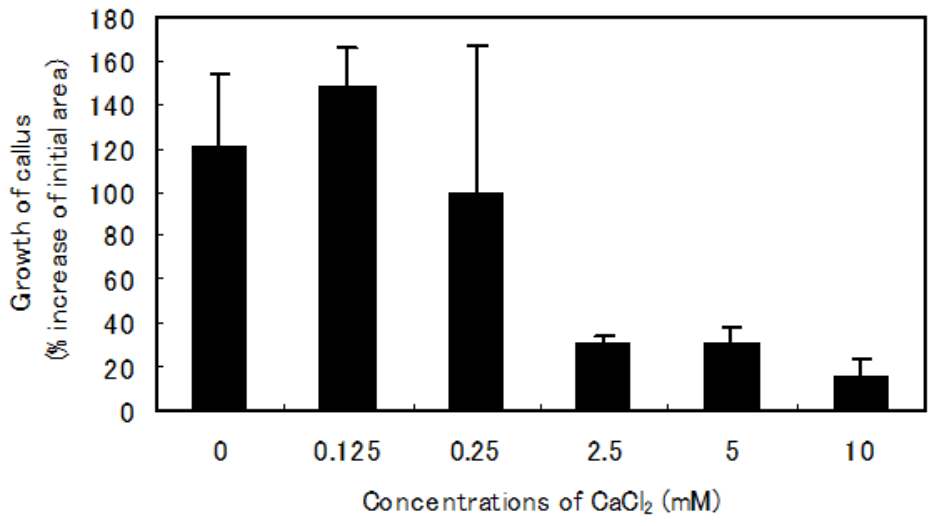

Figure 1. Effect of $\mathrm{CaCl}_{2}$ on the callus growth of high-Ca line of A. alba cotyledon callus. Callus growth (\% increase of initial area) after 31 days of culture was measured using Image $\mathbf{J}$ analysis. Callus was cultured in mAA basal medium without $\mathrm{CaCl}_{2}$ containing $3 \%$ sucrose and $1 \mu \mathrm{M}$ each of 2,4-D and thidiazuron

These findings are consistent with the fact that addition of $10 \mathrm{mM} \mathrm{CaCl}_{2}$ inhibited the growth of cotyledon-origin suspension cells (Hayashi et al., 2009), when the packed cell volume was measured after culture of suspension cells using a 24-well culture plate. In the present study, growth of callus was measured as increased pixel area using Image-J software. Fresh and dry weights of callus were measured after three months of culture, and a similar decrease of growth was obtained depending on the $\mathrm{CaCl}_{2}$ concentration (data not shown). Dry weight was about $5 \%$ of the fresh weight.

The low-Ca callus line was developed from a one-year-old high-Ca line derived from A. alba cotyledons, and it was sub-cultured in $9 \mathrm{~cm}$ diameter petri dishes for more than three years. Although the addition of 3 and $6 \mathrm{mM}$ of $\mathrm{CaCl}_{2}$ inhibited the growth (brown color and smaller size) of A. alba callus in the second sub-culture (Figure 2), deletion of $\mathrm{Ca}^{2+}$ ions in the medium for a long period of sub-culture was challenging, because $\mathrm{Ca}^{2+}$ ions are thought to be indispensable for plants and are included in almost all plant tissue culture media (1-9 mM, Franklin \& Dixon, 1994; Poothong \& Reed, 2015).

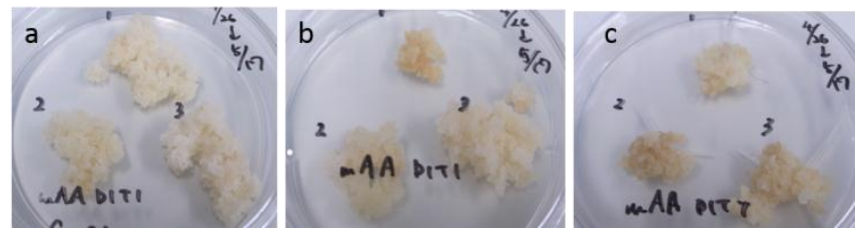

Figure 2. Subculture of low-Ca line of A. alba cotyledon callus, without (a), with $3 \mathrm{mM}$ (b) or $6 \mathrm{mM}$ (c) of $\mathrm{CaCl}_{2}$, cultured in $6 \mathrm{~cm} \varphi$ plastic dishes. $\mathrm{CaCl}_{2}$ at 3 and $6 \mathrm{mM}$ was inhibitory on the callus growth. Basal medium was the same as of Figure 1

\subsection{Ultrastructures of A. alba Callus}

The cotyledon-derived calluses of A. alba, sub-cultured for about two years with (high-Ca line, Figure 3a) and for about one year without (low-Ca line, Figure 3b) $3 \mathrm{mM} \mathrm{CaCl}_{2}$, were observed by conventional electron microscopy. Diameters of cells sub-cultured with and without $3 \mathrm{mM} \mathrm{CaCl}_{2}$, were $\sim 25 \mu \mathrm{m}$ and $\sim 45 \mu \mathrm{m}$, respectively. These cells contained a well-developed central vacuole and the cytoplasmic matrix was located at the peripheral region of the cells and contained of organelles, e.g., nucleus, mitochondria, and amyloplasts. From the ultrastructural observation, no significant difference was observed between the high-Ca line and low-Ca line, except for the electron-dense precipitates in the cell wall (Figure 4). In resin-embedded sections of both callus lines, electron-dense precipitates were observed in the middle lamella of the cell wall, though these precipitates were observed more frequently in the high-Ca line (Figure 4a) than in the low-Ca line (Figure 4b). 

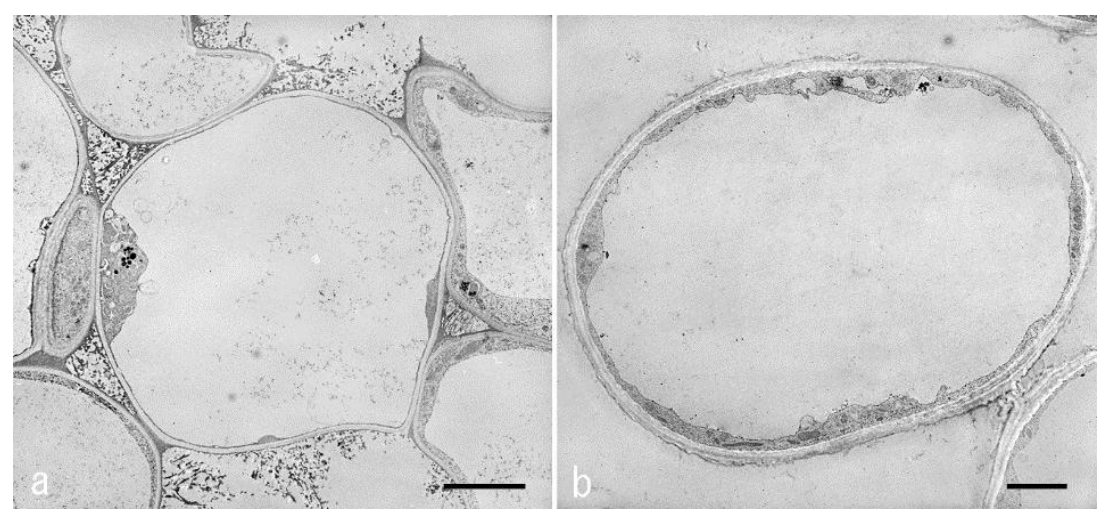

Figure 3. Electron microscope images from the chemically fixed and resin-embedded cell clusters of $A$. alba cotyledon callus. The high-Ca line (a) was cultured with $3 \mathrm{mM}$ of $\mathrm{CaCl}_{2}$, and low-Ca line (b) was cultured without $\mathrm{CaCl}_{2}$. Scale bars, $5 \mu \mathrm{m}$
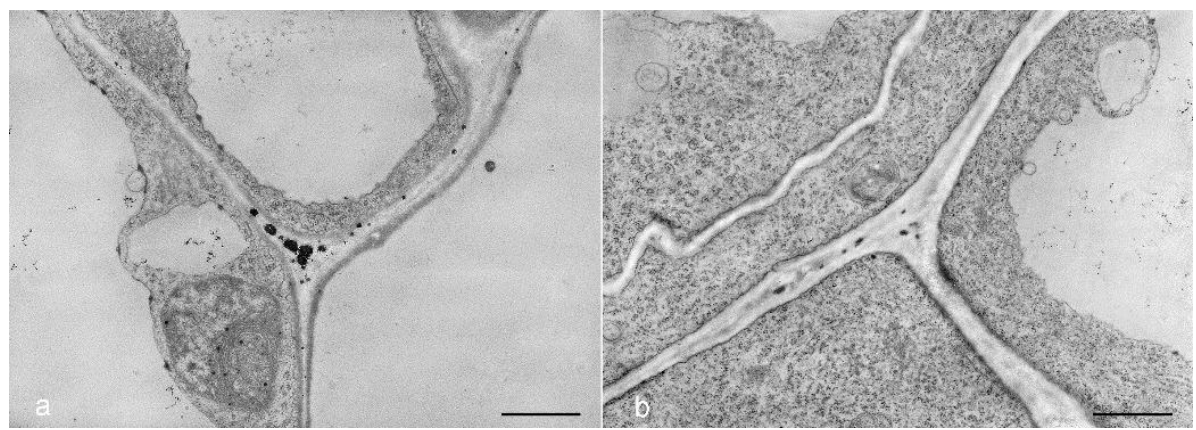

Figure 4. Electron-dense precipitates at the middle lamella of cell wall in A. alba cotyledon callus. The high-Ca line (a) was cultured with $3 \mathrm{mM}$ of $\mathrm{CaCl}_{2}$, and low-Ca line (b) was cultured without $\mathrm{CaCl}_{2}$. Scale bars, $5 \mu \mathrm{m}$

\subsection{Cellular Concentrations of Elements Detected by X-ray Microanalysis of Cryosections}

A spot analysis was carried out at the cell wall, the cytoplasmic matrix, and the vacuolar lumen in the cryosections that were cut from the frozen cell clusters of $A$. alba callus sub-cultured with and without $3 \mathrm{mM}$ $\mathrm{CaCl}_{2}$. The results are summarized in Table 1 (high-Ca line) and Table 2 (low-Ca line). The given elements were those that were detected in X-ray spectra as a significant spectral peak and were included fundamentally in the MS basal medium, and mAA basal medium and are generally found in plant tissues and cells. Concerning the results of Student's $t$ distribution, the differences between the mean values with $P<0.01$ were considered significant.

Table 1. The concentrations of various elements in the cell wall, cytoplasmic matrix and vacuole in a high-Ca line of A. alba cotyledon callus

\begin{tabular}{|c|c|c|c|c|c|c|}
\hline Element & Cell wall & (\%) & Cytoplasmi & matrix $(\%)$ & Vacuole & $(\%)$ \\
\hline $\mathrm{Ca}$ & $36.5 \pm 7.1$ & (34) & $51.2 \pm 11.2$ & $(48)$ & $18.1 \pm 3.1$ & (17) \\
\hline K & $126.3 \pm 24.4$ & (42) & $87.1 \pm 7.3$ & (29) & $87.5 \pm 14.5$ & (29) \\
\hline $\mathrm{Cl}$ & $73.8 \pm 12.6$ & (46) & $52.4 \pm 5.5$ & (33) & $34.9 \pm 6.4$ & (22) \\
\hline $\mathrm{Na}$ & $2.7 \pm 1.8$ & (32) & $3.1 \pm 1.5$ & (37) & $2.6 \pm 1.8$ & (31) \\
\hline $\mathrm{Mg}$ & $13.2 \pm 2.7$ & (28) & $22.7 \pm 6.0$ & (49) & $10.8 \pm 1.8$ & (23) \\
\hline $\mathrm{P}$ & $14.0 \pm 3.0$ & (17) & $59.2 \pm 16.4$ & (73) & $7.5 \pm 2.5$ & (9) \\
\hline $\mathrm{S}$ & $14.0 \pm 2.8$ & (26) & $26.3 \pm 5.0$ & (49) & $13.9 \pm 4.4$ & (26) \\
\hline
\end{tabular}

The values are $\mathrm{mmol} / \mathrm{kg}$ DW (mean \pm S.E.M., $N=10$ ).

The values in parentheses are percentages of each component. 
Table 2. The concentrations of various elements in the cell wall, cytoplasmic matrix and vacuole in a low-Ca line of $A$. alba cotyledon callus

\begin{tabular}{|c|c|c|c|}
\hline Element & Cell wall & Cytoplasmic matrix (\%) & Vacuole $(\%)$ \\
\hline $\mathrm{Ca}$ & $4.6 \pm 1.4^{* 4}$ & $2.6 \pm 1.1^{* 4} \quad(30)$ & $1.6 \pm 0.7 *^{4} \quad(18)$ \\
\hline K & $237.5 \pm 25.0^{* 4} \quad(62)$ & $78.4 \pm 9.8^{* 1}$ & $64.4 \pm 15.0 *^{* 1}$ \\
\hline $\mathrm{Cl}$ & $122.6 \pm 10.4^{* 4} \quad(62)$ & $37.5 \pm 6.0 *^{2}$ & $36.8 \pm 7.7 *^{1}$ \\
\hline $\mathrm{Na}$ & $3.6 \pm 2.0^{* 1}$ & $0 *^{2}$ & $1.9 \pm 1.0 *^{1}$ \\
\hline $\mathrm{Mg}$ & $18.5 \pm 1.7 * 1$ & $9.9 \pm 2.4 *^{2}$ & $9.5 \pm 2.1 *^{1}$ \\
\hline $\mathrm{P}$ & $33.8 \pm 6.8^{* 3}$ & $41.8 \pm 7.2 *^{1} \quad(51)$ & $6.7 \pm 1.3 * 1$ \\
\hline$S$ & $14.3 \pm 3.0 * 1$ & $13.8 \pm 2.7 *^{3} \quad(40)$ & $6.0 \pm 0.7 * 1$ \\
\hline
\end{tabular}

The values are $\mathrm{mmol} / \mathrm{kg} \mathrm{DW}$ (mean \pm S.E.M., $N=10$ ). Significances of difference between the concentration of various elements in high-Ca line and low-Ca line are shown. ${ }^{* 1} P>0.1,{ }^{2} P<0.1,{ }^{3} P<0.05,{ }^{*} P<0.01$.

The values in parentheses are percentages of each component.

\subsubsection{Ca Distribution in Cytoplasmic Matrix}

[Ca] in the cytoplasmic matrix of the high-Ca line was $51.2 \mathrm{mmol} / \mathrm{kg} \mathrm{DW}, 48 \%$. The values are very high, compared with those in $S$. alba $(20.5 \mathrm{mmol} / \mathrm{kg} \mathrm{DW}, 17 \%)$ and those in rice suspension cells $(11.9 \mathrm{mmol} / \mathrm{kg} \mathrm{DW}$, $34 \%$ ) reported previously (Hayatsu et al., 2014). These results suggest that in the high-Ca line of A. alba transport ability of $\mathrm{Ca}^{2+}$ is low from the cytoplasmic matrix to the cell wall or to the vacuole, and the high [Ca] in the cytoplasmic matrix may be related to the lower growth rate of the high-Ca line in the medium containing high concentrations of $\mathrm{CaCl}_{2}$ (Figure 1). Generally a trace amount of $\mathrm{Ca}$ is said to regulate various physiological phenomena of organisms (Plieth \& Trewavas, 2002; Hayatsu \& Suzuki, 2015). The intracellular [Ca] is kept nearly constant to avoid cytotoxic damage induced by increase of intracellular [Ca] (Gilroy, Blowers, \& Trewavas, 1987; Belyavskaya, 1996). In the low-Ca line, [Ca] was reduced dramatically at all cell components, although the low amount of [Ca] was still detected (Table 2). Although pure water was used for medium preparation, the low-Ca line could be sub-cultured for more than three years. These results suggest that the trace amount of $[\mathrm{Ca}]$ might be carried by transfer of callus to fresh medium or that specific mechanism might be working in A. alba cells for accumulation of Ca from trace constituents of chemicals. Since the growth of A. alba callus was promoted by the very low concentrations of $\mathrm{Ca}^{2+}$ (Figure 1), a trace amount of $\mathrm{Ca}^{2+}$ was considered to stimulate the cell growth of $A$. alba callus.

\subsubsection{Ca Distribution in Cell Wall}

The quantitative X-ray microanalysis of the cell wall in A. alba callus observed in cryosections showed that [Ca] in the high-Ca line $(36.5 \mathrm{mmol} / \mathrm{kg} \mathrm{DW}, 34 \%)$ was approximately seven times that of the low-Ca line (4.6 mmol $/ \mathrm{kg} \mathrm{DW}, 52 \%$ ). As reported previously, the quantitative X-ray microanalysis of cryosections of halophilic $S$. alba and glycophyte $O$. sativa cells cultured with $3 \mathrm{mM}$ of $\mathrm{CaCl}_{2}$ showed that a large amount of $\mathrm{Ca}(69.8 \mathrm{mmol} / \mathrm{kg}$ DW, 56\%) distributes in the cell wall of $S$. alba and that low [Ca] (8.2-14.4 mmol $/ \mathrm{kg} \mathrm{DW})$ were found in all cell components of $O$. sativa (Hayatsu et al., 2014). These results showed that high [Ca] in the cell wall of A. alba and $S$. alba cells indicate that halophyte mangrove plants have the ability to accumulate $\mathrm{Ca}$ in the cell wall.

\subsection{3 $\mathrm{K}$ and $\mathrm{Cl}$ Distribution}

The $[\mathrm{Ca}],[\mathrm{K}]$ and $[\mathrm{Cl}]$ in the cell wall were different in the two callus lines of A. alba. In contrast, [Na], [Mg], [P] and $[\mathrm{S}]$ were similar in all components, suggesting that the cellular distributions of these elements were not affected by the deletion of $\mathrm{Ca}^{2+}$ in the medium. In the high-Ca line, [Ca], $[\mathrm{Na}],[\mathrm{Mg}],[\mathrm{P}]$ and $[\mathrm{S}]$, but not $[\mathrm{K}]$ and $[\mathrm{Cl}]$ were mainly high in the cytoplasmic matrix. In contrast, in the low-Ca line, $[\mathrm{Ca}],[\mathrm{K}],[\mathrm{Cl}],[\mathrm{Na}]$ and $[\mathrm{Mg}]$, were mainly high in the cell wall. The concentrations of the elements were lower in the vacuole in both lines of A. alba. $[\mathrm{K}]$ and $[\mathrm{Cl}]$ in the cell wall of low-Ca line of A. alba were twice those of high-Ca line without any significant change of concentration in the cytoplasmic matrix and vacuole.

In higher plants, [Ca] makes the cell wall rigid and subsequently reduces the cell growth (Cooil \& Bonner, 1957; Hayatsu \& Suzuki, 2015). In the low-Ca line of A. alba callus, the increase of $[\mathrm{K}]$ and $[\mathrm{Cl}]$ in the cell wall may be caused by the decrease of $[\mathrm{Ca}]$ in the cell wall and reflect the supply of these ions from the mAA medium including $\mathrm{K}^{+}$and $\mathrm{Cl}^{-}$in high concentrations. In A. alba, possible transport of $[\mathrm{Ca}],[\mathrm{K}]$ and $[\mathrm{Cl}]$ from the cell wall to the cytoplasmic matrix at cell membrane must be reduced by the deletion of $\mathrm{CaCl}_{2}$ in the medium. In contrast, in $S$. alba cells cultured with $3 \mathrm{mM}$ of $\mathrm{CaCl}_{2},[\mathrm{~K}](55 \%)$ and $[\mathrm{Cl}](64 \%)$ were high in the vacuole, suggesting the uniqueness of halophilic $S$. alba suspension cells having high possible transport activities of $[\mathrm{K}],[\mathrm{Cl}]$ and $[\mathrm{Na}]$ 
into the vacuole (Hayatsu et al., 2014).

\subsection{Ca-containing Electron-dense Precipitates in the Cell Wall in the Resin-embedded Section}

$\mathrm{X}$-ray microanalysis was performed on the electron-dense precipitates at the middle lamella of the cell wall in the resin-embedded section. A spectral peak of $\mathrm{Ca}(\mathrm{Ca}-\mathrm{K \alpha}$ at $3690 \mathrm{eV})$ was clearly detected on the electron-dense precipitates in the middle lamella of the cell wall of both callus lines. Spectral peak intensities of $\mathrm{Ca}-\mathrm{K} \alpha$ emissions detected from precipitates in the high-Ca line were several times higher than those in the low-Ca line. Our observations suggest that the electron-dense precipitates contain $\mathrm{Ca}$, and that the heavy accumulation of $\mathrm{Ca}$ in the middle lamella of the cell wall of the high-Ca line (Figure 4a) might be related to the inhibition of growth by high $\mathrm{Ca}^{2+}$ concentrations in callus culture of high-Ca line of A. alba (Figure 1). The high $[\mathrm{Ca}]$ in the cell wall of high-Ca line (Table 1) might reflect accumulation of Ca-containing electron-dense precipitates (Figure 4), which was not observed in cryosections of A. alba.

Electron-dense structures of plant cells contain a high amount of $\mathrm{Ca}$, such as gravitropic soybean cells, which was confirmed by X-ray microanalysis (Hayatsu et al., 2012). Heavy deposition of electron-dense precipitates in the middle lamella of cell wall (Figure 4a) has been reported in radish and corn roots treated with high concentrations of lead (Inoue et al., 2013) or lanthanum (Hayatsu, Ono, \& Suzuki, unpublished). The existence of these heavy metals in the electron-dense precipitates in the cell wall was also confirmed by X-ray microanalysis, suggesting that it is related to the accumulation and tolerance to these heavy metals. On the other hand, heavy accumulation of electron-dense precipitates in the middle lamella of cell walls are observed neither in the cells of halophyte mangrove $S$. alba nor in those of glycophyte $O$. sativa cultured with $3 \mathrm{mM} \mathrm{CaCl}_{2}$ (Hayatsu et al., 2014), which did not inhibit their growth.

\subsection{Effects of $\mathrm{CaCl}_{2}$ on Protoplast Cultures of A. alba}

To determine the effect of removal of cell wall, we isolated protoplasts and cultured them in the media with and without $3 \mathrm{mM}$ of $\mathrm{CaCl}_{2}$. When isolated, diameters of protoplasts of two lines of $A$. alba were less than $50 \mu \mathrm{m}$ in 0.6 M mannitol solution. Osmotic condition, 0.6 M, instead of 1.2 M sorbitol (Hasegawa et al., 2011, 2013) was used after optimization. Small protoplasts $(20 \mu \mathrm{m}$ diameter) were found in the high-Ca line, while only large protoplasts (30 to $40 \mu \mathrm{m}$ ) were found in the low-Ca line. This might reflect the diameter difference found by the conventional electron microscopy (Figure 3). In protoplast cultures for plant regeneration, CPW salts, which include high concentrations of $\mathrm{Mg}^{2+}$ and $\mathrm{Ca}^{2+}$ ions, are occasionally used for obtaining viable protoplasts (Franklin \& Dixon, 1994). In the present study and in our protoplast research (Hasegawa et al., 2013), isolation and purification of protoplasts was performed in cell wall degrading enzymes without using buffer salts, and without addition of $\mathrm{Mg}^{2+}$ and $\mathrm{Ca}^{2+}$ ions. The procedure is necessary to know the direct effects of these ions in the culture medium.
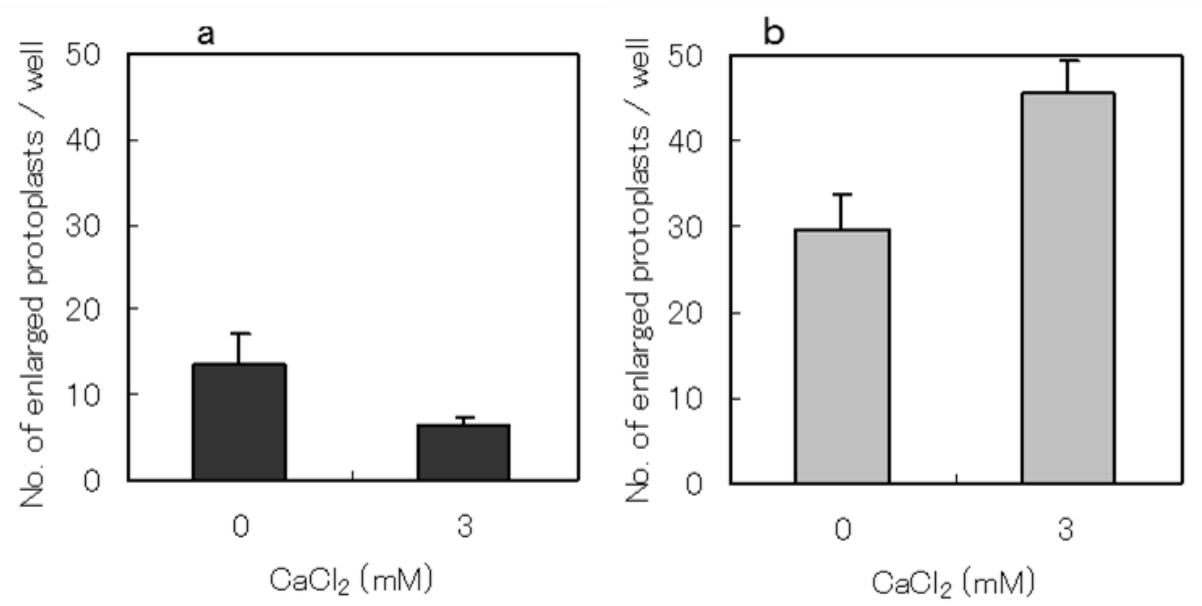

Figure 5. Effect of $\mathrm{CaCl}_{2}$, on the growth of protoplasts of a high-Ca line (a) and low-Ca line (b) of A. alba cotyledon callus. The protoplasts were cultured in mAA basal medium containing $3 \%$ sucrose, $0.6 \mathrm{M}$ mannitol and $1 \mu \mathrm{M}$ each of 2,4-D and thidiazuron with and without $3 \mathrm{mM}$ of $\mathrm{CaCl}_{2}$ 

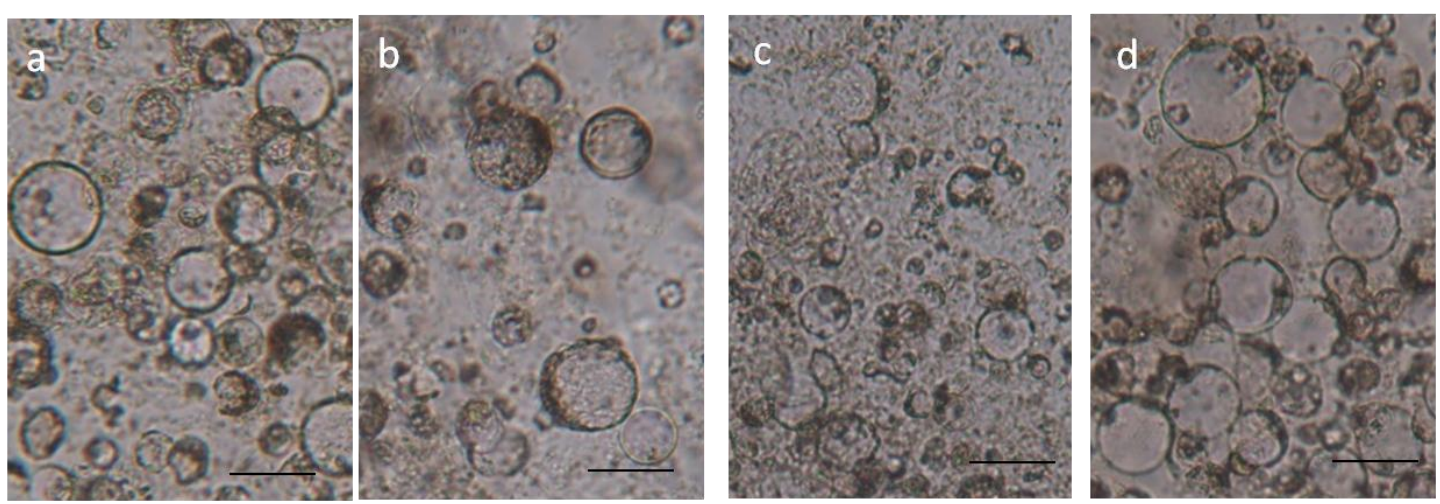

Figure 6. Effect of $\mathrm{CaCl}_{2}$, on the growth of protoplasts in a high-Ca line (a, b) and low-Ca line (c, d) of $A$. alba cotyledon callus. The protoplasts were cultured in the same basal medium as of Figure 5 except for $0.1 \mu \mathrm{M}$ each of 2,4-D and thidiazuron, with (b, d) and without (a, c) $3 \mathrm{mM}$ of $\mathrm{CaCl}_{2}$. Scale bars, $50 \mu \mathrm{m}$

Figure 5a shows the inhibitory effects of $3 \mathrm{mM} \mathrm{CaCl}_{2}$ in the medium on the protoplast cultures of a high-Ca line of A. alba cotyledon-callus. Similar $\mathrm{Ca}^{2+}$ effects were obtained in different plant growth regulator conditions, i.e., $0.1 \mu \mathrm{M}$ each of 2,4-D and thidiazuron (Figure 6a, b). These findings are consistent with the inhibition of growth of callus by $2.5 \mathrm{mM}$ or more of $\mathrm{CaCl}_{2}$ (Figure 1) and with that of protoplast culture of cotyledon-derived suspension culture (Hasegawa et al., 2013), though the optimal osmotic condition was $1.2 \mathrm{M}$ sorbitol in the protoplast culture of suspension cells of A. alba (Hasegawa et al., 2011). Table 1 shows high [Ca] at the cell wall in the high-Ca line. Protoplast isolation must reduce the $[\mathrm{Ca}]$ distribution at the outer cell. However, a high cytoplasmic [Ca] and further application of $\mathrm{Ca}^{2+}$ ions in the medium might inhibit the growth of protoplasts (Figure 5a).

Figure 5b (low-Ca line) shows better growth than in Figure 5a, and the stimulatory effects of addition of $3 \mathrm{mM}$ $\mathrm{CaCl}_{2}$ in the medium. Addition of $\mathrm{CaCl}_{2}$ increased cell enlargement of protoplasts. These are opposite the effects of $\mathrm{Ca}^{2+}$ on callus (Figure 1) and protoplast (Figure 5a) growth of the high-Ca line. Different hormonal conditions, $0.1 \mu \mathrm{M}$ of 2,4-D and thidiazuron gave similar results (Figure 6c, d). In the protoplast isolation of low-Ca line, by removal of $[\mathrm{Ca}]$ at the cell wall, the amount of $[\mathrm{Ca}]$ in the cytoplasmic or vacuolar components might become lower than needed for culture. The overall results suggested that an appropriate, but very low amount of [Ca] at the cell wall is needed for cell growth in A. alba.

As $\mathrm{Ca}^{2+}$ is generally a prerequisite for culture of plant tissue and protoplasts, deletion of $\mathrm{Ca}^{2+}$ in medium is unusual. However, in this study, cotyledon-callus of halophyte A. alba could be sub-cultured for years in the absence of $\mathrm{Ca}^{2+}$ in the medium (low-Ca line), and a much lower cellular [Ca] was found using X-ray microanalysis. Very recently, we found that deletion of $\mathrm{Ca}^{2+}$ in cultures of cotyledons and hypocotyls of another seaward-side grown Avicennia mangrove, A. marina, caused much better growth than usual media (Sasamoto \& Mochida, 2015). As $\mathrm{Ca}^{2+}$ in the culture media had similar inhibitory effects on growth in both Avicennia species, Avicennia species might have a specific cellular mechanism for accumulation of $\mathrm{Ca}$ in the cell wall and in the cytoplasmic matrix, but less transport activity of $\mathrm{Ca}$ into the vacuole. In another halophyte mangrove, $S$. alba (Hayatsu et al., 2014), in the usual medium ( $\left.3 \mathrm{mM}-\mathrm{CaCl}_{2}\right)$, similarly, Ca accumulated in the cell wall, but the [Ca] in the cytoplasmic matrix was low. The [Ca] in the cytoplasmic matrix and vacuole was very low in the high $\mathrm{Na}^{+}$ in the medium, which is optimum for cell growth of $S$. alba. Therefore, in cell cultures of halophilic mangrove species, decrease of cellular [Ca] might be the most important factor for their cellular growth. Cellular [Ca] was measured effectively by X-ray microanalysis of cryosections.

\section{Acknowledgments}

This study was partly supported by the research fund of the Research Institute for Integrated Science, Kanagawa University.

\section{References}

Akatsu, M., Hosoi, Y., Sasamoto, H., \& Ashihara, H. (1996). Purine metabolism in cells of a mangrove plant, Sonneratia alba, in tissue culture. Journal of Plant Physiology, 149, 133-137.

https://doi.org/10.1016/S0176-1617(96)80185-4 
Belyavskaya, N. A. (1996). Free and membrane-bound calcium in microgravity and microgravity effects at the membrane level. Advances in Space Research, 17, 169-177. https://doi.org/10.1016/0273-1177(95)00631-N

Cooil, B., \& Bonner, J. (1957). The nature of growth inhibition by calcium in the Avena coleoptile. Planta, 48, 696-723. https://doi.org/10.1007/BF01911596

Dagar, J. C., Singh, N. T., \& Mongia, A. D. (1993). Characteristics of mangrove soils and vegetation of Bay Islands in India. In H. Lieth, \& A. A. Masoom (Eds.), Towards the rational use of high salinity tolerant plants. Vol.1. Deliberations about high salinity tolerant plants and ecosystems (pp. 59-80). Kluwer Academic. https://doi.org/10.1007/978-94-011-1858-3_6

Franklin, C. I., \& Dixon, R. A. (1994). Initiation and maintenance of callus and cell suspension cultures. In R. A. Dixon, \& R. A .Gonzales (Eds.), Plant Cell Culture. A Practical Approach (pp. 1-25). Oxford: IRL Press.

Gilroy, S., Blowers, D. P., \& Trewavas, A. J. (1987). Calcium: a regulation system emerges in plant cells. Development, 100, 181-184.

Hasegawa, A., Hayashi, S., Kurita, A., Kaai, F., Kawana, Y., Fukumoto, T., \& Sasamoto, H. (2011). Stimulatory and inhibitory effects of abscisic acid on cell growth in protoplast cultures and the relation to its endogenous levels in Avicenniaceae mangrove cells. Mangrove Science, 8, 11-18.

Hasegawa, A., Kurita, A., Hayashi, S., Fukumoto, T., \& Sasamoto, H. (2013). Halophilic and salts tolerant protoplast cultures of mangrove plants, Sonneratia alba and Avicennia alba. Plant Biotechnology Reports, 7, 205-209. https://doi.org/ 10.1007/s11816-012-0251-2

Hasegawa, A., Oyanagi, T., Minagawa, R., Fujii, Y., \& Sasamoto, H. (2014). An inverse relationship between allelopathic activity and salt tolerance in suspension cultures of three mangrove species, Sonneratia alba, $S$. caseolaris and S. ovata: development of a bioassay method for allelopathy, the protoplast co-culture method. Journal of Plant Research, 127, 755-761. https://doi.org/10.1007/s10265-014-0651-1

Hayashi, S., Kuriyama, S., Kawana, Y., Hasegawa, A., Kurita, A., Minagawa, R., \& Sasamoto, H. (2009). Stimulatory effects of sea salts on cell growth in liquid culture of Avicenniaceae mangrove. Plant Biotechnology, 26, 561-564. https://doi.org/10.5511/plantbiotechnology.26.561

Hayatsu, M., Ono, M., Hamamoto, C., \& Suzuki, S. (2012). Cytochemical and electron probe X-ray microanalysis studies on the distribution change of intracellular calcium in columella cells of soybean roots under simulated microgravity. Journal of Electron Microscopy, 61, 57-69. https://dx.doi.org/10.1093/jmicro/dfr095

Hayatsu, M., Suzuki, S., Hasegawa, A., Tsuchiya, S., \& Sasamoto, H. (2014). Effect of $\mathrm{NaCl}$ on ionic content and distribution in suspension-cultured cells of the halophyte Sonneratia alba versus the glycophyte Oryza sativa. Journal of Plant Physiology, 171, 1385-1391. https://doi.org/10.1016/j.jplph.2014.06.008

Hayatsu, M., \& Suzuki, S. (2015). Electron probe X-ray microanalysis studies on the distribution change of intra- and extracellular calcium in the elongation zone of horizontally reoriented soybean roots. Microscopy, 64(5), 327-334. https://doi.org/10.1093/jmicro/dfv031

Inoue, H., Fukuoka, D., Tatai, Y., Kamachi, H., Hayatsu, M., Ono, M., \& Suzuki, S. (2013). Properties of lead deposits in cell walls of radish (Raphanus sativus) roots. Journal of Plant Research, 126, 51-61. https://doi.org/10.1007/s10265-012-0494-6

Kawana, Y., \& Sasamoto, H. (2008). Stimulation effects of salts on growth in suspension culture of a mangrove plant, Sonneratia alba, compared with another mangrove, Bruguiera sexangula and non-mangrove tobacco BY-2 cells. Plant Biotechnology, 25, 151-155. https://doi.org/10.5511/plantbiotechnology.25.151

Kawana, Y., Yamamoto, R., Mochida, Y., Suzuki, K., Baba, S., \& Sasamoto, H. (2007). Generation and maintenance of suspension cultures from cotyledons and their organogenic potential of two mangrove species, Sonneratia alba and S. caseolaris. Plant Biotechnology Reports, 1, 219-226. https://doi.org/10.1007/s11816-007-0035-2

Kawana, Y., Sasamoto, H., \& Ashihara, H. (2008). Mechanism of salt tolerance in mangrove plants. Bulletin of the Society of Sea Water Science, Japan, 62, 207-214. (in Japanese with English abstract) https://doi.org/10.11457/swsj1965.62.207

Murashige, T., \& Skoog, F. (1962). A revised medium for rapid growth and bioassay with tobacco tissue cultures. Physiologia Plantarum, 15, 473-497. https://doi.org/10.1111/j.1399-3054.1962.tb08052.x

Plieth, C., \& Trewavas, A. J. (2002). Reorientation of seedlings in the Earth's gravitational field induces 
cytosolic calcium transients. Plant Physiology, 129, 786-796. https://doi.org/10.1104/pp.011007

Poothong, S., \& Reed, B. M. (2015). Increased $\mathrm{CaCl}_{2}, \mathrm{MgSO}_{4}$, and $\mathrm{KH}_{2} \mathrm{PO}_{4}$ improve the growth of micropropagated red respberries. In Vitro Cellular and Developmental Biology Plant, 51, 648-658. https://doi.org/10.1007/s11627-015-9720-y

Rasband, W. S. (1997-2016). Image J. U. S. National Institute of Health, Bethesda, Maryland, USA, http://imagej.nih.gov/ij

Sasamoto, H., \& Mochida, Y. (2015). Ca inhibits callus induction from seeds of a mangrove plant, Avicennia marina (in Japanese). Abstracts of the 21st Annual Meeting of Japan Society for Mangroves, p. 6.

Spalding, M. D., Kainuma, M., \& Collins, L. (2010). World Atlas of Mangroves. London: Earthscan Publications.

Tomlinson, P. B. (1986). The Botany of Mangroves. London: Cambridge University Press.

Tsuchiya, S., Ogita, S., Kawana, Y., Oyanagi, T., Hasegawa, A., \& Sasamoto, H. (2013). Relation between amino acids profiles and recalcitrancy of cell growth or salt tolerance in tissue and protoplast cultures of three mangrove species, Avicennia alba, Bruguiera sexangula, and Sonneratia alba. American Journal of Plant Sciences, 4, 1366-1374. https://doi.org/10.4236/ajps.2013.47167

Yamamoto, R., Kawana, Y., Minagawa, R., \& Sasamoto, H. (2011). Effects of sea salts on induction of cell proliferation in liquid cultures of mangrove plants, Sonneratia caseolaris and S. alba. American Journal of Plant Sciences, 2, 35-42. https://doi.org/10.4236/ajps.2011.21004

\section{Appendix}

Image J Analysis of Callus Growth
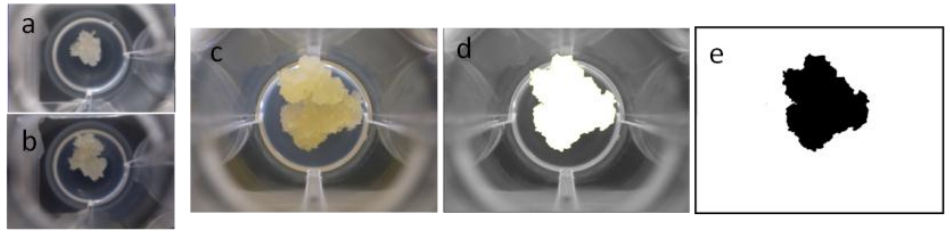

Figure 7. Digital images of calluses in each well of a 24 well culture plate (a, b, c), and steps of Image $\mathbf{J}$ analysis of an example of callus (c, d, e). The original view of callus (c) was cut with freehand selection and converted to binary image to demonstrate the transverse section (d), and then the section image was inverted from white to black (e). Area of transverse section (e) was measured in pixels. Images a (at 0 day) and b (at 22 day of culture) were derived from the same well

\section{Copyrights}

Copyright for this article is retained by the author(s), with first publication rights granted to the journal.

This is an open-access article distributed under the terms and conditions of the Creative Commons Attribution license (http://creativecommons.org/licenses/by/3.0/). 